\title{
IDENTIFIKASI KEBUTUHAN SISTEM MONITORING DAN PENGENDALIAN MULTI-PROYEK KONSTRUKSI DENGAN METODE HOUSE OF QUALITY Studi Kasus: Dinas Pekerjaan Umum Kabupaten Gresik
}

\author{
Agus Siswanto, Imam Baihaqi \\ Magister Manajemen Teknologi, Institut Teknologi Sepuluh Nopember Surabaya \\ e-mail: agus.siswanto058@gmail.com,ibaihaqi@mb.its.ac.id
}

\begin{abstract}
Every year, the committing officer, then called as PPK, as the manager of the owner construction project in the local government and its team often handles more than 50 (fifty) construction projects termed "multi construction projects". This study aims to identify the design needs of monitoring and controlling multi-construction projects system in the local government in order to be developed as a reference needs of monitoring and controlling system software. This study began by identifying the needs of PPK and stakeholders through interviews related to the system software that will be developed. The interview results were then grouped and described as "customer requirement attributes" and then made the "importance" level values of those attributes as a questionnaire. The quality result concluded that all customer requirements attributes were considered important with the total score range at 123-171 from the "importance" standard score is 105. Then a functional requirement was made for each customer requirement and analyzed using a method adopted from house of quality (HoQ) with final results are; the highest percentage from 36 (thirty six) of the relative importance weight from functional requirements is 6.42 percent and the lowest is 1.24 percent with 5 (five) highest sequences are 4.78 percent-6.42 percent.
\end{abstract}

Keywords: project management, control system design, multi construction projects, PPK/project manager owner, house of quality (HoQ)

\section{PENDAHULUAN}

Salah satu program tahunan sasaran pembangunan di pemerintah daerah adalah peningkatan kualitas infrastruktur daerah, dalam hal ini ujung tombaknya adalah dinas pekerjaan umum. Pejabat pembuat komitmen (PPK) adalah pejabat yang bertanggung jawab pelaksanaan pengadaan barang atau jasa, di antaranya pekerjaan proyek konstruksi. Sesuai yang terjadi di lapangan selama ini di pemerintah daerah, seorang PPK selaku manajer proyek owner pemerintah tak jarang meng-handle lebih dari lima puluh paket pekerjaan konstruksi pada satu tahun anggaran berjalan yang diistilahkan di sini sebagai multi proyek konstruksi. Menurut (Irawan \& Syairudin, 2015) bahwa multiple project memiliki lebih dari satu tujuan walaupun dilakukan pada lokasi yang sama maupun berbeda. Aritua et al. (2009) menyatakan bahwa sebagian besar proyek merupakan bagian dari lingkungan multi-proyek. Pengelolaan beberapa proyek menyajikan tantangan yang secara fundamental berbeda dari manajemen proyek tunggal. Perkembangan teori terbaru dalam filsafat teori kompleksitas memberikan dasar untuk memperoleh wawasan proposisi bahwa manajemen multi-proyek bukan merupakan ekstensi atau versi ditingkatkan dari manajemen proyek tunggal. Pada hakikatnya lingkungan multi-proyek menunjukkan karakteristik dari sistem adaptif kompleks yang menawarkan pendekatan baru untuk manajer proyek. 
Menurut Gray \& Larson (2011) evaluasi dan kontrol adalah bagian dari pekerjaan setiap manajer proyek. Jika dilihat dari scope yang begitu luas berupa pengendalian multi proyek dengan waktu yang terbatas satu tahun anggaran berjalan, tentulah sangat berat bagi PPK dalam melaksanakan tugasnya sebagai manajer proyek owner untuk melakukan monitoring dan pengendalian proyek di atas. Gray \& Larson (2011) juga menyampaikan bahwa untuk kontrol yang efektif, manajer proyek perlu suatu sistem informasi tunggal untuk mengumpulkan data dan melaporkan kemajuan biaya, jadwal, dan spesifikasi.

Pada studi kasus di Dinas Pekerjaan Umum Kabupaten Gresik, salah satu PPK pada bidang Tata Bangunan dan Pengawasan mencoba membangun sistem monitoring proyek yang dinamakan "Simpro" pada tahun 2015 dan pertama diaplikasikan pada tahun 2016 dengan harapan aplikasi tersebut digunakan sebagai alat monitoring bagi PPK pada proyek multi konstruksi yang ditanganinya. Dari pengamatan peneliti ternyata Simpro yang telah dibangun kurang maksimal dimanfaatkan karena ternyata banyak kebutuhan stakeholder yang tidak terakomodasi oleh Simpro. Saat ini PPK menggunakan cara lain untuk memonitor perkembangan proyekproyeknya melalui media WhatsApp, dan cara manual yang tidak terorganisasi dan terstruktur. Media WhatsApp hanya dipakai untuk informasi yang sebatas foto-foto aktual, peringatan-peringatan sementara, dan informasi lain yang bersifat umum. Sedangkan cara manual yang dimaksud adalah PPK melakukan monitoring proyek dengan menanyakan perkembangan proyek secara langsung kepada para stakeholder terkait seperti pejabat pelaksana teknis kegiatan, staf koordinator proyek, konsultan pengawas dan kontraktor. Monitoring dan kontrol yang efektif yang di harapan dari Simpro seperti pengum- pulan data, pelaporan kemajuan biaya, jadwal, dan spesifikasi aktual di lapangan tidak diperoleh manfaatnya secara maksimal oleh PPK.

Masalah lain yang dihadapi oleh PPK dalam menangani multi proyek ini antara lain: perbedaan waktu (time schedule) pada setiap paket pekerjaan sehingga pemetaan schedule masingmasing kegiatan proyek sering tak terpantau, titik lokasi proyek menyebar, dan dimungkinkan terletak pada lokasi yang terpencil seperti Pulau Bawean sehingga sulit untuk memonitor perkembangan schedule performance kontraktor dengan cepat pada masing-masing paket kegiatan proyek sehingga antisipasi solusi atas hambatan proyek terlambat dilakukan, serta terpenuhinya kualitas mutu konstruksi pada setiap pekerjaan proyek konstruksi sesuai kontrak pada masing-masing proyek.

Berdasarkan gambaran di atas maka perlu dilakukan identifikasi terhadap kebutuhan software sistem monitoring dan pengendalian berupa respons teknis (functional requirements) yang sesuai dengan harapan PPK dan tim owner untuk dapat dikembangkan menjadi prototype pengembangan sistem monitoring tahap desain sistem.

\section{KERANGKA TEORETIS}

Kerangka teori di bawah ini menunjukkan beberapa teori yang terkait dengan sistem informasi manajemen proyek sebagai dasar rujukan kebutuhan teknis desain sistem monitoring dan pengendalian multi proyek konstruksi yang akan dikembangkan.

\section{Sistem Informasi Manajemen Proyek}

Keberhasilan pengelolaan proyek salah satunya ditentukan oleh tersedianya informasi yang dibutuhkan oleh pihak manajemen untuk membuat keputusan. Keputusan yang tepat dipenga- 
ruhi tersedia tidaknya informasi yang akurat, tepat waktu, dan lengkap mengenai jadwal, biaya, dan performansi. Untuk itu perlu suatu sistem yang mampu menyediakan kebutuhan informasinya (Santosa, 2009).

Secara umum, sistem informasi manajemen proyek diharapkan mampu sebagai berikut.

1. Menyediakan informasi yang perlu untuk melakukan perencanaan, pengendalian dan ringkasan-ringkasan dokumen.

2. Memisahkan data dari system informasi komputer yang lain ke dalam database proyek.

3. Mengintegrasikan pekerjaan, biaya, tenaga kerja, dan informasi jadwal untuk menghasilkan perencanaan, pengendalian dan laporan ringkas untuk manajer proyek, orang-orang fungsional dan pihak manajemen yang lebih tinggi.

\section{Struktur Sistem Informasi Monitoring Proyek}

Menurut Gray \& Larson (2011), sebuah sistem monitoring proyek melibatkan pemantauan sebagai berikut.

1. Data yang harus dikumpulkan meliputi: status proyek (jadwal dan biaya), sisa biaya yang diperlukan untuk penyelesaian proyek, tanggal proyek akan selesai, potensi masalah yang harus ditangani, kegiatan out-of-control yang memerlukan intervensi, cost and/or schedule overruns dan alasan penyebabnya, serta prediksi waktu overrun untuk menyelesaikan proyek.

2. Pengumpulan data dan analisisnya meliputi: siapa yang bertugas mengumpulkan data proyek, bagaimana data dikumpulkan, kapan data dikumpulkan, siapa yang akan mengompilasi dan menganalisis data.

3. Laporan dan pelaporan meliputi: siapa yang menerima laporan, bagaimana laporan ditransmisikan, kapan laporan didistribusikan.
Biasanya, laporan kemajuan proyek dirancang dan dikomunikasikan secara tertulis atau bentuk lisan. Secara umum, progress report mengikuti hal-hal berikut.

1. Progress sejak laporan terakhir.

2. Status proyek saat ini: jadwal (schedule), biaya (cost), dan lingkup (scope).

3. Cumulative trends.

4. Masalah dan isu-isu sejak laporan terakhir: tindakan dan solusi masalah lebih awal, perubahan pekerjaan baru, dan identifikasi masalah.

5. Rencana tindakan korektif.

Mengingat struktur sistem informasi dan sifat output-nya, kita dapat menggunakan sistem untuk tampilan interface dan memfasilitasi proses pengendalian proyek. Tampilan interface ini harus relevan dan simpel jika menginginkan kontrol yang efektif.

\section{Evaluasi Kemajuan Pekerjaan dan Pengukuran} Kinerja

Menurut (Gray \& Larson, 2011) evaluasi dan kontrol adalah bagian dari pekerjaan setiap manajer proyek. Kontrol dengan "sering inspeksi" dan/atau "keterlibatan" dapat mengatasi masalah lebih detail dalam proyek-proyek kecil. Tapi proyek-proyek besar membutuhkan beberapa bentuk kontrol formal. Kontrol oleh orang yang bertanggung jawab, mencegah masalah kecil untuk kemudian menjadi masalah besar, dan terus fokus.

Kontrol adalah salah satu hal yang sering diabaikan dari manajemen proyek. Sayangnya, tidak jarang untuk menemukan resistensi untuk mengontrol proses. Pada intinya, mereka yang meminimalkan pentingnya kontrol melewatkan kesempatan besar untuk menjadi manajer yang efektif dan memungkinkan organisasi untuk men- 
dapatkan keunggulan kompetitif. Mengabaikan kontrol dalam organisasi dengan beberapa proyek bahkan lebih serius. Untuk kontrol yang efektif, manajer proyek perlu suatu sistem informasi tunggal untuk mengumpulkan data dan melaporkan kemajuan biaya, jadwal, dan spesifikasi.

\section{Kontrak Konstruksi Pemerintah}

Laporan kontrak konstruksi pemerintah merupakan salah satu pedoman yang berlaku untuk menjalankan proses pelaksanaan proyek konstruksi bagi PPK dan stakeholder yang terlibat. Laporan hasil pekerjaan sesuai Permen PUPR No.31/PRT/M/2015 (2015) diuraikan sebagai berikut.

1. Pemeriksaan pekerjaan dilakukan selama pelaksanaan kontrak untuk menetapkan volume pekerjaan atau kegiatan yang telah dilaksanakan guna pembayaran hasil pekerjaan. Hasil pemeriksaan pekerjaan dituangkan dalam laporan kemajuan hasil pekerjaan.

2. Untuk kepentingan pengendalian dan pengawasan pelaksanaan pekerjaan, seluruh aktivitas kegiatan pekerjaan di lokasi pekerjaan dicatat dalam buku harian sebagai bahan laporan harian pekerjaan yang berisi rencana dan realisasi pekerjaan harian.

3. Laporan harian berisi:

a. jenis dan kuantitas bahan yang berada di lokasi pekerjaan;

b. penempatan tenaga kerja untuk tiap macam tugasnya;

c. jenis, jumlah dan kondisi peralatan;

d. jenis dan kuantitas pekerjaan yang dilaksanakan;

e. keadaan cuaca termasuk hujan, banjir dan peristiwa alam lainnya yang berpengaruh terhadap kelancaran pekerjaan; dan f. catatan-catatan lain yang berkenaan dengan pelaksanaan.

4. Laporan harian dibuat oleh penyedia, apabila diperlukan diperiksa oleh konsultan, dan disetujui oleh wakil PPK (pejabat pembuat komitmen).

5. Laporan mingguan terdiri dari rangkuman laporan harian dan berisi hasil kemajuan fisik pekerjaan dalam periode satu minggu serta hal-hal penting yang perlu ditonjolkan.

6. Laporan bulanan terdiri dari rangkuman laporan mingguan dan berisi hasil kemajuan fisik pekerjaan dalam periode satu bulan, serta hal-hal penting yang perlu ditonjolkan.

7. Untuk merekam kegiatan pelaksanaan pekerjaan konstruksi, PPK, dan penyedia membuat foto-foto dokumentasi dan video pelaksanaan pekerjaan di lokasi pekerjaan sesuai kebutuhan.

\section{Proses Pembuatan Perangkat Lunak}

Pada proses pembuatan perangkat lunak, peneliti membatasi penelitiannya sampai tahap kebutuhan perangkat lunak dan desain perangkat lunak. Menurut SWEBOK Guide V3.0 (2014) tahapan di atas diuraikan sebagai berikut.

1. Kebutuhan perangkat lunak (software requirements)

Software requirements memperhatikan tentang elisitasi, analisis, spesifikasi, dan validasi persyaratan perangkat lunak serta pengelolaan persyaratan selama siklus hidup seluruh produk lunak.

2. Desain perangkat lunak

Proses penyusunan desain perangkat lunak terdiri dari dua hal berikut.

a. Desain dasar perangkat lunak

Pada tahapan ini dilakukan penyusunan konsep desain perangkat lunak secara 


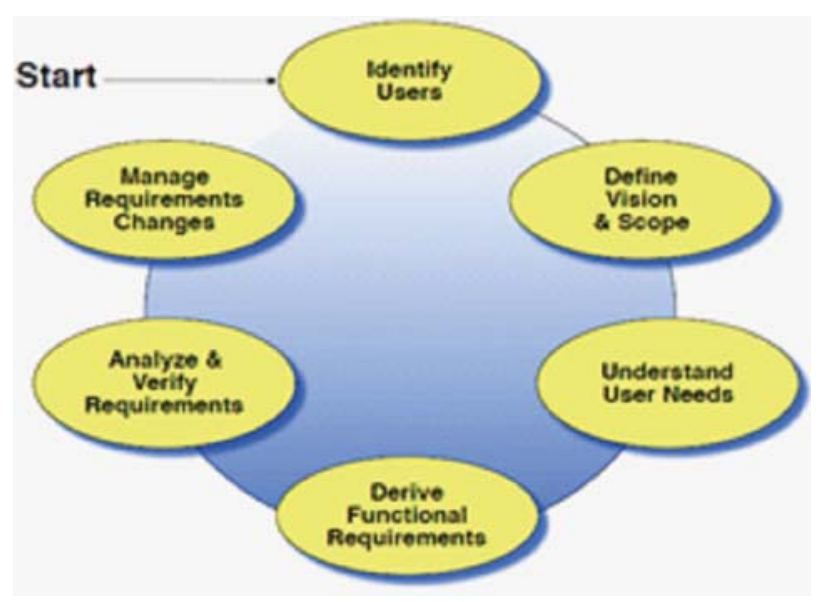

Gambar Requirements Development \& Management Process

Sumber: Potter \& Sakry (2014)

umum, kemudian dilakukan desain isi dari perangkat lunak tersebut, selanjutnya desain proses dari perangkat lunak yang akan disusun, kemudian dilakukan penyusunan prinsip dari perangkat lunak tersebut.

b. Isu kunci dalam perangkat lunak

Proses ini dilakukan dengan penyusunan isu-isu kunci yang terkait dengan perangkat lunak yang akan disusun. Hal tersebut akan berkaitan erat dengan fitur-fitur apa saja yang akan ditanamkan pada perangkat lunak tersebut.

Pembahasan penelitian akan disesuaikan dengan lingkup penelitian yaitu pada "isu kunci dalam perangkat lunak" berupa identifikasi kebutuhan desain sistem monitoring dan pengendalian multi proyek konstruksi.

\section{House of Quality}

(Akao, 1994) menyampaikan bahwa quality function deployment (QFD) mempunyai kemampuan unik menerjemahkan permintaan pengguna ke dalam persyaratan teknis. Menurut (Tapke,
Muller, Johnson, \& Sieck, 1997), setiap perusahaan selalu menggunakan data dan informasi untuk membantu dalam proses perencanaan. QFD menggunakan format matriks untuk menangkap sejumlah isu yang sangat penting untuk proses perencanaan. Metode the house of quality (HoQ) matrix banyak digunakan dengan menerjemahkan kebutuhan pelanggan, berdasarkan riset pemasaran, dan benchmarking data dalam jumlah yang sesuai target rekayasa yang harus dipenuhi oleh desain produk baru. Pada

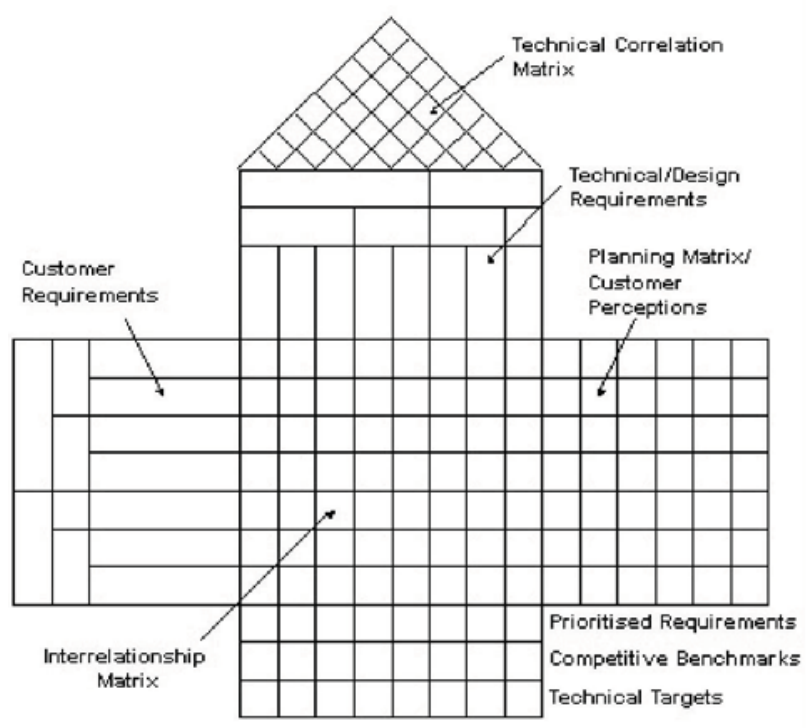

Gambar House of Quality

dasarnya, HoQ adalah saraf pusat dan mesin yang menggerakkan seluruh proses QFD. Menurut Hauser \& Clausing (1988) HoQ adalah "Semacam peta konseptual yang menyediakan sarana untuk perencanaan interfunctional dan komunikasi." Ada banyak bentuk yang berbeda dari house of quality, namun kemampuannya untuk disesuaikan dengan persyaratan dari masalah khusus membuat sistem yang sangat kuat dan andal untuk digunakan. Format umum terdiri dari enam komponen utama. Ini termasuk kebutuhan pelanggan, persyaratan teknis, matriks perencanaan, sebuah keterkaitan matriks, ma- 
triks korelasi teknis, dan prioritas/tolok ukur dan target teknis bagian.

\section{METODE PENELITIAN}

\section{Kerangka Penelitian}

Berdasarkan tujuan penelitian ini yaitu mengidentifikasi kebutuhan sistem monitoring dan pengendalian multi proyek konstruksi yang akan didesain, peneliti mengumpulkan data keinginan/kebutuhan melalui wawancara kepada 30 (tiga puluh) responden antara lain PPK dan stakeholder yang terlibat dalam pelaksanaan proyek konstruksi di Kabupaten Gresik. Menurut Alwi (2015) yang mengutip Roscoe (1975) menyatakan bahwa ukuran sampel lebih dari 30 dan kurang dari 500 adalah tepat untuk kebanyakan penelitian. Kemudian dari hasil wawancara tersebut dikelompokkan atau diklasifikasikan atas pendapat/masukan yang sama atau sejenis yang disebut peneliti sebagai atribut keinginan/kebutuhan (customer requirements). Dari hasil atribut tersebut kemudian peneliti menyebarkan kuesioner kepada PPK dan timnya untuk mendapatkan score dari masing-masing hasil atribut customer requirements yang kemungkinan bersamaan atau secara parallel akan dibuatkan respons teknis (functional requirements) terhadap atribut-atribut tersebut. Selanjutnya dilakukan analisis dengan mengadopsi kajian house of quality (HoQ). Dari analisis tersebut akan didapatkan respons teknis yang merupakan hasil identifikasi kebutuhan desain sistem monitoring dan pengendalian multi proyek konstruksi.

\section{Wawancara Responden dan Scoring}

Untuk mengidentifikasi kebutuhan/keinginan stakeholder akan sistem monitoring dan pengendalian yang akan didesain, peneliti mela- kukan wawancara kepada 30 (tiga puluh) responden yaitu PPK dan stakeholder yang terlibat seperti yang diuraikan di bawah ini.

1. PA (pengguna anggaran) yang merupakan atasan langsung dari PPK dan menguasai pekerjaan di bidang konstruksi pekerjaan umum.

2. PPK, di mana PPK dapat mampu menggambarkan keinginan seorang project manajer owner pada fase monitoring dan pengendalian multi proyek di Dinas Pekerjaan Umum Kabupaten Gresik.

3. PPTK (pejabat pelaksana teknis kegiatan), di mana PPTK merupakan bawahan langsung dari PPK dan dianggap sebagai wakil in house PPK.

4. Staf teknis, di mana staf teknis yang merupakan kepanjangan tangan monitoring dan pengendalian lapangan dari PPTK yang bersentuhan langsung dengan penyedia baik di lapangan maupun proses administratif, sehingga dapat memberikan masukan kebutuhan sistem monitoring dan pengendalian konstruksi yang akan dibangun.

5. Penyedia jasa konstruksi (kontraktor), di mana kontraktor yang akan diwawancarai mencerminkan kualifikasi kontraktor kecil (pekerjaan konstruksi di bawah 2,5 miliar) dan kualifikasi kontraktor non-kecil (pekerjaan konstruksi di atas 2,5 miliar). Personel yang diwawancarai adalah manajer proyek kontraktor atau pelaksana proyek.

6. Penyedia jasa konsultasi pengawasan konstruksi, di mana konsultan pengawas yang akan diwawancarai mempunyai pengalaman pengawasan atas pekerjaan konstruksi pada kontraktor kecil dan atau non-kecil. Personel yang diwawancarai adalah tim leader atau tenaga ahli konsultan pengawas.

Penentuan score atribut customer requirements yang dianggap penting dilakukan peneliti 
melalui penyebaran kuesioner kepada unsur PPK dan timnya dengan pertimbangan bahwa monitoring dan pengendalian pada sistem yang akan dibangun adalah kepentingan besar dari unsur ini. Sedangkan unsur kontraktor dan konsultan pengawas dianggap sebagai objek dari pelaksanaan monitoring dan pengendalian itu sendiri. Hal ini dilakukan sebagai gambaran dan validasi kebutuhan yang dianggap penting, seperti yang disampaikan (Lam, 2015) bahwa diperlukan gambaran dan validasi kebutuhan pendekatan untuk menemukan kebutuhan desain yang paling penting. Gambaran dan validasi tingkat "penting” atribut keinginan/kebutuhan dan scoring dapat dilihat pada Tabel 1 berikut.

Tabel 1 Scoring Tingkat "Penting”

\begin{tabular}{|l|c|}
\hline \multicolumn{1}{|c|}{ Klasifikasi } & $\begin{array}{c}\text { Pembobotan } \\
\text { (Score) }\end{array}$ \\
\hline Sangat Penting Sekali (SPS) & 5 \\
\hline Sangat Penting (SP) & 4 \\
\hline Penting (P) & 3 \\
\hline Kurang Penting (KP) & 2 \\
\hline Tidak Penting (TP) & 1 \\
\hline
\end{tabular}

Setelah dilakukan scoring maka akan didapatkan data relative weight dari masing-masing atribut customer requirements dengan cara membagi score customer requirements dengan total score (penjumlahan keseluruhan score atribut).

\section{Respons Teknis (Functional Requirements)}

Hasil dari atribut customer requirements yang dianggap penting, masing-masing dibuatkan respons teknis berdasarkan pertimbangan teori yang disampaikan pada kajian pustaka dan ide peneliti berdasarkan pengalaman penanganan monitoring dan pengendalian konstruksi sebagai langkah pemenuhan kebutuhan teknis sistem yang akan dibangun. Rangkaian penentuan customer requirements dan functional requirements kemudian dianalisis menggunakan metode yang diadopsi dari house of quality (HoQ) untuk mendapatkan identifikasi kebutuhan sistem monitoring dan pengendalian multi proyek konstruksi.

\section{Analisis House of Quality}

Menurut Tapke et al. (1997) dalam teknik analisis HoQ terdapat enam tahapan utama yang akan dilakukan sebagai berikut.

1. Klasifikasi kebutuhan/keinginan

2. Menentukan kebutuhan/keinginan (customer requirements)

3. Perencanaan matrix penentuan respons teknis (functional requirements)

Pada proses ini akan disusun matrix respons teknis (functional requirements) yang akan digunakan sebagai proses analisis. Matrix tersebut berbentuk seperti rumah.

4. Keterkaitan matrix

Pada proses ini dilakukan proses perhitungan yang membandingkan antara keinginan stakeholder (customer requirements) dengan respons teknis (functional requirements). Selain itu, hasil perhitungan matrix ini juga akan menunjukkan hubungan antar-desain functional requirements.

5. Teknis properti dan target

Pada proses ini dilakukan pencatatan terhadap prioritas serta membandingkan nilai kompetitif dan tingkat kesulitan dalam pengembangan masing-masing kebutuhan.

6. Penentuan desain target dan benchmark Pada proses ini dilakukan penentuan desain yang paling ideal dari proses analisis HoQ yang telah dilaksanakan. 


\section{HASIL DAN PEMBAHASAN}

\section{Klasifikasi Customer Requirements}

Dari hasil wawancara terhadap tiga puluh responden yang dipilih terdapat 149 poin pernyataan dan diketahui beberapa pernyataan dari responden mempunyai kesamaan maka peneliti kemudian melakukan pengelompokan atau klasi- fikasi pernyataan menjadi atribut customer requirements. Hasil klasifikasi atribut customer requirements dapat dilihat pada Tabel 2 . Beberapa point customer requirements pada Tabel 2 angka 25, 27, 28, 35, 36 tidak dapat digunakan pada ini karena dianggap peneliti di luar lingkup penelitian sehingga didapatkan 35 klasifikasi customer requirements.

Tabel 2 Klasifikasi Customer Requirements

\begin{tabular}{|c|c|}
\hline No. & Klasifikasi Customer Requirements \\
\hline 1 & Dapat diakses dari mana saja \\
\hline 2 & Dapat dijadikan sebagai alat (tools) pengawasan yang efektif \\
\hline 3 & $\begin{array}{l}\text { Dapat mengakomodasi perubahan kontrak (addendum kontrak) yang diakibatkan } \\
\text { dari kesepakatan PCM, MC0\%, dan CCO }\end{array}$ \\
\hline 4 & Dapat melakukan pembatasan waktu (time limit) pelaporan dari penyedia \\
\hline 5 & Dapat menampilkan dokumentasi foto dan video terkini (update visual report) \\
\hline 6 & Hanya dapat diakses oleh stake holder proyek yang terlibat/berkepentingan \\
\hline 7 & Dapat mencetak langsung laporan proyek terkini (update) sesuai kebutuhan \\
\hline 8 & $\begin{array}{l}\text { Dapat menunjukkan perkembangan proyek (progress report) terkini termasuk deviasi } \\
\text { progress }\end{array}$ \\
\hline 9 & $\begin{array}{l}\text { Dapat menunjukkan alur layanan surat menyurat Serah Terima Pertama/PHO dan } \\
\text { Serah Terima Akhir/FHO }\end{array}$ \\
\hline 10 & $\begin{array}{l}\text { Dapat menunjukkan dan menyediakan laporan memorial asset secara langsung (siap } \\
\text { printout) }\end{array}$ \\
\hline 11 & $\begin{array}{l}\text { Dapat menampilkan informasi permasalahan proyek terkini dan } \\
\text { tanggapannya/respons }\end{array}$ \\
\hline 12 & $\begin{array}{l}\text { Menyediakan form/template isian laporan proyek (laporan harian, mingguan, } \\
\text { bulanan) }\end{array}$ \\
\hline 13 & Memperingkas dan memudahkan teknis pengisian laporan perkembangan progress \\
\hline 14 & $\begin{array}{l}\text { Memberikan informasi kelengkapan administrasi proyek yang dibutuhkan oleh } \\
\text { pemeriksa pekerjaan (PPHP, PPK, PPTK, dan Tim Teknis) dalam rangka } \\
\text { mempercepat proses pencairan prestasi pekerjaan dan serah terima }\end{array}$ \\
\hline 15 & $\begin{array}{l}\text { Dapat mengorganisasikan jadwal rapat (site meeting) proyek untuk menghindari } \\
\text { jadwal rapat proyek bersamaan }\end{array}$ \\
\hline 16 & $\begin{array}{l}\text { Dapat memberikan informasi/pantauan kinerja personel tenaga ahli baik pihak } \\
\text { kontraktor maupun konsultan pengawas }\end{array}$ \\
\hline 17 & Mengakomodasi laporan konsultan pengawas sesuai KAK \\
\hline 18 & $\begin{array}{l}\text { Dapat digunakan sebagai alat pengendali kualitas (quality control) pekerjaan berupa } \\
\text { izin pelaksanaan, permintaan persetujuan (approval) material, checklist sebelum } \\
\text { terpasang, checklist daftar cacat, checklist sebelum PHO dan checklist sebelum FHO }\end{array}$ \\
\hline 19 & $\begin{array}{l}\text { Mengakomodasi daftar simak (outline) spesifikasi untuk mempermudah proses } \\
\text { pelaksanaan dan pemantauan pekerjaan }\end{array}$ \\
\hline 20 & Menyajikan informasi cuaca pada saat pekerjaan dilaksanakan \\
\hline 21 & $\begin{array}{l}\text { Dapat memonitor status keuangan (tahapan pembayaran) penyerapan anggaran } \\
\text { proyek \& mempermudah alur proses pencairan keuangan proyek melalui } \\
\text { otomatisasi persyaratan pencairan }\end{array}$ \\
\hline 22 & Mengantisipasi overload lalu lintas (kecepatan $\&$ kapasitas) layanan data \\
\hline
\end{tabular}




\begin{tabular}{|l|l|}
\hline 23 & Kemudahan akses ke sistem monitoring \& pengendalian \\
\hline 24 & Sistem bisa dimanfaatkan untuk DPU secara keseluruhan \\
\hline 25 & Dapat mengintegrasikan antara program ini dengan laporan format P1 Dinas \\
\hline 26 & Dapat menginformasikan lokasi proyek (seperti di Google Maps) \\
\hline 27 & Mengatur regulasi review karya perencanaan untuk konsultan MK \\
\hline 28 & $\begin{array}{l}\text { Sudah menetapkan SOP dari owner. (SOP Owner akan disandingkan dengan SOP } \\
\text { dari konsultan MK untuk dicari penyelesaian terbaik) }\end{array}$ \\
\hline 29 & Dapat menghubungkan antara gambar kerja dengan RKS \\
\hline 30 & $\begin{array}{l}\text { Dapat digunakan sebagai alat (tools) untuk memonitoring performa keuangan } \\
\text { kontraktor utama untuk menghindari kejadian pihak sub kontraktor yang tidak } \\
\text { terbayar }\end{array}$ \\
\hline 31 & $\begin{array}{l}\text { Dapat memberikan informasi performa masing-masing kontraktor yang terlibat pada } \\
\text { semua proyek PPK pada tampilan awal interface sehingga dapat diketahui status } \\
\text { proyek dan rencana penanganannya bila terjadi permasalahan (overrun) }\end{array}$ \\
\hline 32 & $\begin{array}{l}\text { Critical path method (CPM)/jalur lintasan kritis agar dimasukkan dalam tampilan } \\
\text { interface (baik CPM per proyek maupun secara general/ status proyek keseluruhan) }\end{array}$ \\
\hline 33 & $\begin{array}{l}\text { Quality assurance (jaminan kualitas) dimasukkan dalam system monitoring agar ada } \\
\text { dokumen kontrol atas pelaksanaan pekerjaan konstruksi }\end{array}$ \\
\hline 34 & $\begin{array}{l}\text { Memasukkan dokumen rencana percepatan pada kontraktor jika terjadi } \\
\text { keterlambatan pekerjaan (schedule overrun) }\end{array}$ \\
\hline 35 & Mengakomodasi manajemen antrean entry data \\
\hline 36 & Informasi dapat tersampaikan kepada direktur perusahaan yang terlibat pada proyek \\
\hline 37 & $\begin{array}{l}\text { Memberikan laporan jadwal (schedule report) kedatangan dan rencana kedatangan } \\
\text { material-material penting yang perlu indent/import }\end{array}$ \\
\hline 38 & $\begin{array}{l}\text { Dapat digunakan untuk monitoring sub kontraktor terkait pekerjaan spesialis yang } \\
\text { harus dikerjakan oleh orang-orang spesialis juga agar kualitas pekerjaan dapat } \\
\text { terjamin }\end{array}$ \\
\hline 39 & $\begin{array}{l}\text { Menginformasikan jadwal/schedule tes running MEEP terkait pemfungsian bangunan } \\
\text { gedung yang akan diserahterimakan }\end{array}$ \\
\hline 40 & $\begin{array}{l}\text { Menginformasikan jadwal waktu dari instansi lain yang diperlukan kepastiannya } \\
\text { untuk pemfungsian bangunan seperti PLN, PDAM, Telkom, GAS, dll. }\end{array}$ \\
\hline
\end{tabular}

\section{Penentuan Customer Requirements}

Setelah dilakukan klasifikasi terhadap kebutuhan stakeholder, langkah selanjutnya adalah melakukan validasi tingkat "Penting" dari customer requirements tersebut melalui penyebaran kuesioner disertai penjelasan singkat kepada 41 (empat puluh satu) responden dari perwakilan owner untuk menilai kualitas/tingkat "penting" atribut customer requirements.

Dengan meninjau nilai tengah (P) pada tingkat "penting" dari 35 atribut customer requirements maka score tingkat penting "P" adalah $3 \times 35=105$. Jika dilihat dari hasil score dan urutan score pada Tabel 3 diketahui nilai terendah dari total score adalah 123 maka dapat disimpulkan bahwa seluruh atribut tersebut merupakan hal "penting" yang perlu dimasukkan sebagai atribut customer requirements untuk mengidentifikasi kebutuhan sistem monitoring dan pengendalian multi proyek konstruksi.

\section{Penentuan Respons Teknis (Functional Require- ments)}

Setelah melihat tabulasi customer requirements, peneliti memutuskan menghilangkan tiga atribut karena dianggap telah memenuhi tujuan dari penelitian ini antara lain: "bisa dimanfaatkan 
Tabel 3 Scoring Customer Requirements

\begin{tabular}{|c|c|c|c|c|c|c|c|c|c|c|c|c|}
\hline \multirow{2}{*}{ No. } & \multirow{2}{*}{ CUSTOMER REQUIREMENTS } & \multicolumn{5}{|c|}{ KESELURUHAN } & \multicolumn{5}{|c|}{ SCORING } & \multirow{2}{*}{$\begin{array}{l}\text { TOTAL } \\
\text { SCORE }\end{array}$} \\
\hline & & $\mathrm{TP}$ & KP & $p$ & SP & SPS & 1 & 2 & 3 & 4 & 5 & \\
\hline 1 & menunjukkan progress report updote & 0 & 0 & 9 & 16 & 16 & 0 & 0 & 27 & 64 & 80 & 171 \\
\hline 2 & updote visuol report & 0 & 0 & 11 & 16 & 14 & 0 & 0 & 33 & 64 & 70 & 167 \\
\hline 3 & menginformasikan kelengkapan administras & 0 & 2 & 8 & 16 & 15 & 0 & 4 & 24 & 64 & 75 & 167 \\
\hline 4 & bisa dimanfaatkan untuk DPU keseluruhan & 0 & 0 & 16 & 9 & 16 & 0 & 0 & 48 & 36 & 80 & 164 \\
\hline 5 & alat (tools) pengawasan yang efektif & 0 & 0 & 13 & 18 & 10 & 0 & 0) & 39 & 72 & 50 & 161 \\
\hline 6 & diakses dari mana saja & 0 & 1 & 13 & 17 & 10 & 0 & 2 & 39 & 68 & 50 & 159 \\
\hline 7 & cetak langsung laporan proyek terkini & 1 & 1 & 14 & 12 & 13 & 1 & 2 & 42 & 48 & 65 & 158 \\
\hline 8 & permasalahan proyek terkini dan respon & 0 & 0 & 14 & 19 & 8 & 0 & 0) & 42 & 76 & 40 & 158 \\
\hline 9 & alat pengendali kualitas & 0 & 3 & 12 & 15 & 11 & 0 & 6 & 36 & 60 & 55 & 157 \\
\hline 10 & akses terbatas stokeholder & 0 & 3 & 15 & 12 & 11 & 0 & 6 & 45 & 48 & 55 & 154 \\
\hline 11 & kemudahan akses SIMULTIPRO & 0 & 1 & 20 & 8 & 12 & 0 & 2 & 60 & 32 & 60 & 154 \\
\hline 12 & memudahkan pengisian laporan perkembangan progress & 0 & 5 & 9 & 20 & 7 & 0 & 10 & 27 & 80 & 35 & 152 \\
\hline 13 & menginformasikan lokasi proyek & 1 & 3. & 14 & 15 & 8 & 1 & 6 & 42 & 60 & 40 & 149 \\
\hline 14 & pantauan kinerja personel tenaga ahli & 0 & 2 & 18 & 16 & 5 & 0 & 4 & 54 & 64 & 25 & 147 \\
\hline 15 & template isian laporan proyek & 0 & 6 & 10 & 21 & 4 & 0 & 12 & 30 & 84 & 20 & 146 \\
\hline 16 & menginformasikan performa kontraktor & 0 & 1 & 23 & 12 & 5 & 0 & 2 & 69 & 48 & 25 & 144 \\
\hline 17 & menyediakan laporan memorial asset & 0 & 3 & 22 & 9 & 7 & 0 & 6 & 66 & 36 & 35 & 143 \\
\hline 18 & addendum kontrak ( $\mathrm{MCO}$, dan CCO) & 0 & 4 & 19 & 13 & 5 & 0 & 8 & 57 & 52 & 25 & 142 \\
\hline 19 & pembatasan waktu pemasukan laporan penyedia & 0 & 3 & 20 & 14 & 4 & 0 & 6 & 60 & 56 & 20 & 142 \\
\hline 20 & mengakomodasi laporan konsultan pengawas & 0 & 4 & 20 & 11 & 6 & 0 & 8 & 60 & 44 & 30 & 142 \\
\hline 21 & Quality Assuronce (jaminan kualitas) & 0 & 1 & 22 & 16 & 2 & 0 & 2 & 66 & 64 & 10 & 142 \\
\hline 22 & rencana percepatan pekerjaan jika terjadi overrun & 0 & 2 & 21 & 15 & 3 & 0 & 4 & 63 & 60 & 15 & 142 \\
\hline 23 & memonitor status penyerapan anggaran proyek & 0 & 5) & 19 & 12 & 5 & 0 & 10) & 57 & 48 & 25 & 140 \\
\hline 24 & daftar simak (outline) spesifikasi & 0 & 4 & 20 & 14 & 3 & 0 & 8 & 60 & 56 & 15 & 139 \\
\hline 25 & jadwal tes running MEEP & 1 & 4 & 19 & 12 & 5 & 1 & 8 & 57 & 48 & 25 & 139 \\
\hline 26 & menunjukkan alur layanan surat menyurat PHO\&FHO & 0 & 4 & 23 & 11 & 3 & 0 & 8 & 69 & 44 & 15 & 136 \\
\hline 27 & jadwal kedatangan kedatangan material penting & 1 & 5 & 19 & 12 & 4 & 1 & 10 & 57 & 48 & 20 & 136 \\
\hline 28 & mengorganisasikan jadwal rapat proyek & 0 & 7 & 20 & 10 & 4 & 0 & 14 & 60 & 40 & 20 & 134 \\
\hline 29 & Critical Poth Method (CPM) & 1 & 6 & 18 & 13 & 3 & 1 & 12 & 54 & 52 & 15 & 134 \\
\hline 30 & menghubungkan antara gambar kerja dengan RKS & 3 & 6 & 16 & 10 & 6 & 3 & 12 & 48 & 40 & 30 & 133 \\
\hline 31 & jadwal instansi lain (PLN, POAM, Telkom, GAS, dII) & 0 & 3 & 29 & 5 & 4 & 0 & 6 & 87 & 20 & 20 & 133 \\
\hline 32 & monitoring sub kontraktor spesialis & 2 & 3 & 22 & 12 & 2 & 2 & 6 & 66 & 48 & 10 & 132 \\
\hline 33 & informasi cuaca & 1 & 7 & 22 & 10 & 1 & 1 & 14 & 66 & 40 & 5 & 126 \\
\hline 34 & memonitoring performa kuangan kontraktor utama & 0 & 10 & 20 & 9 & 2 & 0 & 20 & 60 & 36 & 10 & 126 \\
\hline 35 & mengantisipasi overload lalulintas data & 1 & 9 & 22 & 7 & 2 & 1 & 18 & 66 & 28 & 10 & 123 \\
\hline
\end{tabular}


untuk DPU keseluruhan, diakses dari mana saja, alat (tools) pengawasan yang efektif”. Ide respons teknis peneliti dapat dilihat pada Tabel 4.

\section{Hasil Analisis HouseofQuality (Hoq)}

Pada proses ini dilakukan proses perhitungan dengan memberikan penilaian hubungan

Tabel 4 Respons Teknis

\begin{tabular}{|c|c|}
\hline Customer Requirements & Respons Teknis/Functional Requirements \\
\hline menunjukkan progress report update & kurva "S"/diagram batang \\
\hline update visual report & tools foto \& video \\
\hline $\begin{array}{l}\text { menginformasikan kelengkapan } \\
\text { administrasi proyek }\end{array}$ & $\begin{array}{l}\text { status centang pada kelengkapan administrasi ming- } \\
\text { guan }\end{array}$ \\
\hline cetak langsung laporan proyek terkini & integrasi sistem \& auto pdf (print out) \\
\hline $\begin{array}{l}\text { permasalahan proyek terkini dan } \\
\text { respons }\end{array}$ & fitur permasalahan terkini $\&$ hasil rapat \\
\hline alat pengendali kualitas & $\begin{array}{l}\text { - Diagram alur monitoring quality performance } \\
\text { (SOP quality performance) } \\
\text { - template form pengajuan material } \\
\text { - form checklist sebelum material terpasang untuk } \\
\text { disetujui pemasangannya } \\
\text { - status persetujuan (centang) pada pengajuan } \\
\text { quality performance }\end{array}$ \\
\hline akses terbatas stakeholder & privilege login system \\
\hline kemudahan akses SIMULTIPRO & $\begin{array}{l}\text { download template RAB excel yg terverifikasi \& ter- } \\
\text { validasi admin }\end{array}$ \\
\hline $\begin{array}{l}\text { memudahkan pengisian laporan } \\
\text { perkembangan progress }\end{array}$ & $\begin{array}{l}\text { isian tabulasi excel volume mingguan terpasang (ter- } \\
\text { integrasi) }\end{array}$ \\
\hline menginformasikan lokasi proyek & fitur lokasi (Google Maps) \\
\hline pantauan kinerja personel tenaga ahli & $\begin{array}{l}\text { - tabulasi T. Ahli termasuk identitasnya } \\
\text { - } \text { validasi T.A kontraktor \& konsultan pengawas }\end{array}$ \\
\hline template isian laporan proyek & isian template lap. Harian, mingguan, bulanan \\
\hline $\begin{array}{l}\text { menginformasikan performa } \\
\text { kontraktor }\end{array}$ & tools tren progress performa \\
\hline menyediakan laporan memorial asset & template data memorial asset \\
\hline addendum kontrak (MC0\%, dan CCO) & $\begin{array}{l}\text { download template RAB ADDENDUM excel yg ter- } \\
\text { verifikasi \& tervalidasi admin }\end{array}$ \\
\hline $\begin{array}{l}\text { pembatasan waktu pemasukan laporan } \\
\text { penyedia }\end{array}$ & pembatasan waktu login system \\
\hline $\begin{array}{l}\text { mengakomodasi laporan konsultan } \\
\text { pengawas }\end{array}$ & $\begin{array}{l}\text { template laporan konsultan pengawas sesuai KAK } \\
\text { pengawasan standar }\end{array}$ \\
\hline quality assurance (jaminan kualitas) & isian tabulasi jaminan kualitas \\
\hline $\begin{array}{l}\text { rencana percepatan pekerjaan jika } \\
\text { terjadi overrun }\end{array}$ & $\begin{array}{l}\text { tools upload rencana percepatan (termasuk kurva "S" } \\
\text { percepatan) }\end{array}$ \\
\hline $\begin{array}{l}\text { memonitor status penyerapan anggaran } \\
\text { proyek }\end{array}$ & $\begin{array}{l}\text { fitur status keuangan proyek (nilai kontrak, uang } \\
\text { muka, pencairan) }\end{array}$ \\
\hline daftar simak (outline) spesifikasi & tabulasi outline spesifikasi \\
\hline jadwal tes running MEEP & fitur jadwal pengetesan \\
\hline $\begin{array}{l}\text { menunjukkan alur layanan surat } \\
\text { menyurat PHO\&FHO }\end{array}$ & $\begin{array}{l}\text { diagram alir (gambar) yang diletakkan pada fitur ce- } \\
\text { tak PHO \& FHO }\end{array}$ \\
\hline
\end{tabular}




\begin{tabular}{|l|l|}
\hline jadwal kedatangan material penting & tabulasi jadwal kedatangan material penting \\
\hline mengorganisasikan jadwal rapat proyek & fitur jadwal rapat proyek \\
\hline critical path method (CPM) & tools upload CPM oleh kontraktor \\
\hline $\begin{array}{l}\text { menghubungkan antara gambar kerja } \\
\text { dengan RKS }\end{array}$ & atribut status RKS pada gambar kerja \\
\hline $\begin{array}{l}\text { jadwal instansi lain (PLN, PDAM, } \\
\text { Telkom, GAS, dll) }\end{array}$ & $\begin{array}{l}\text { fitur/tabulasi info jadwal kesepakatan dengan instan- } \\
\text { si lain }\end{array}$ \\
\hline monitoring sub kontraktor spesialis & fitur \& tabulasi sub kontraktor \\
\hline informasi cuaca & fitur/tabulasi informasi cuaca pada laporan harian \\
\hline $\begin{array}{l}\text { memonitoring performa keuangan } \\
\text { kontraktor utama }\end{array}$ & $\begin{array}{l}\text { informasi data keuangan kontraktor dari hasil doku- } \\
\text { men lelang (BLP) }\end{array}$ \\
\hline mengantisipasi overload lalu lintas data & server online (cloud) \\
\hline
\end{tabular}

(relationship) antara atribut customer requirements dan atribut functional requirements. $\mathrm{Hu}-$ bungan antar-atribut yang kuat akan diberikan nilai bobot 9 (sembilan), sedang diberikan nilai bobot tiga, dan lemah diberikan nilai bobot 1 (satu).

Langkah selanjutnya adalah memberikan penilaian keterkaitan (correlations) antar atribut functional requirements untuk ditentukan atribut mana yang saling mendukung keterkaitannya dan bahkan bisa jadi terdapat atribut respons teknis yang menyebabkan menurunkan nilai respons yang lain. Untuk atribut respons teknis yang saling mendukung akan diberikan tenda positif (+), sedangkan yang dapat menurunkan respons teknis yang lain akan diberikan tanda negatif (-). Pada langkah ini keterkaitan antarrespons teknis tidak terdapat nilai negatif (-) maka tidak terdapat atribut yang menurunkan nilai respons terhadap atribut lainnya. Langkah analisis house of quality dilakukan oleh peneliti dengan menggunakan software "Extended HOQ_Multi.xlt” (“QFD Online - Free House of Quality (QFD) Templates for Excel,” n.d.). Hasil tabulasi penilaian hubungan antara customer requirements dan functional requirements dapat dilihat pada Tabel 5. Sedangkan hasil korelasi antar-functional requirements dapat dilihat pada Tabel 6 .
Pada hasil kesimpulan analisis software ini menunjukkan urutan tingkat "penting” dari respons teknis/functional requirements yang dikemukakan oleh peneliti. Urutan tingkat penting atribut respons teknis tersebut merupakan hasil identifikasi kebutuhan sistem monitoring dan pengendalian multi proyek konstruksi untuk dapat dikembangkan sebagai acuan dalam pengembangan software sistem. Kesimpulan analisis HoQ dapat dilihat pada Tabel 7.

\section{KESIMPULAN \& SARAN}

\section{Kesimpulan}

Penelitian ini telah mendapatkan hal-hal sebagai berikut:

1. Didapatkan 35 atribut customer requirements yang semuanya dianggap penting dengan score tertinggi 171 dan score terendah 123 .

2. Didapatkan bobot relative importance dari 36 (tiga puluh enam) functional requirements tertinggi 6,42 persen dan terendah 1,24 persen dengan 5 (lima) bobot tertinggi adalah 4,78 persen sampai dengan 6,42 persen antara lain: privilege login system, Kurva "S", isian tabulasi excel volume mingguan terpasang (terintegrasi), validasi tenaga ahli kontraktor dan konsultan pengawas, serta tools foto dan video. 
Agus Siswanto \& Imam Baihaqi, Identifikasi Kebutuhan Sistem Monitoring dan Pengendalian Multi-Proyek Konstruksi dengan Metode House of Quality

\section{Tabel 5 Relationship between Requirements}

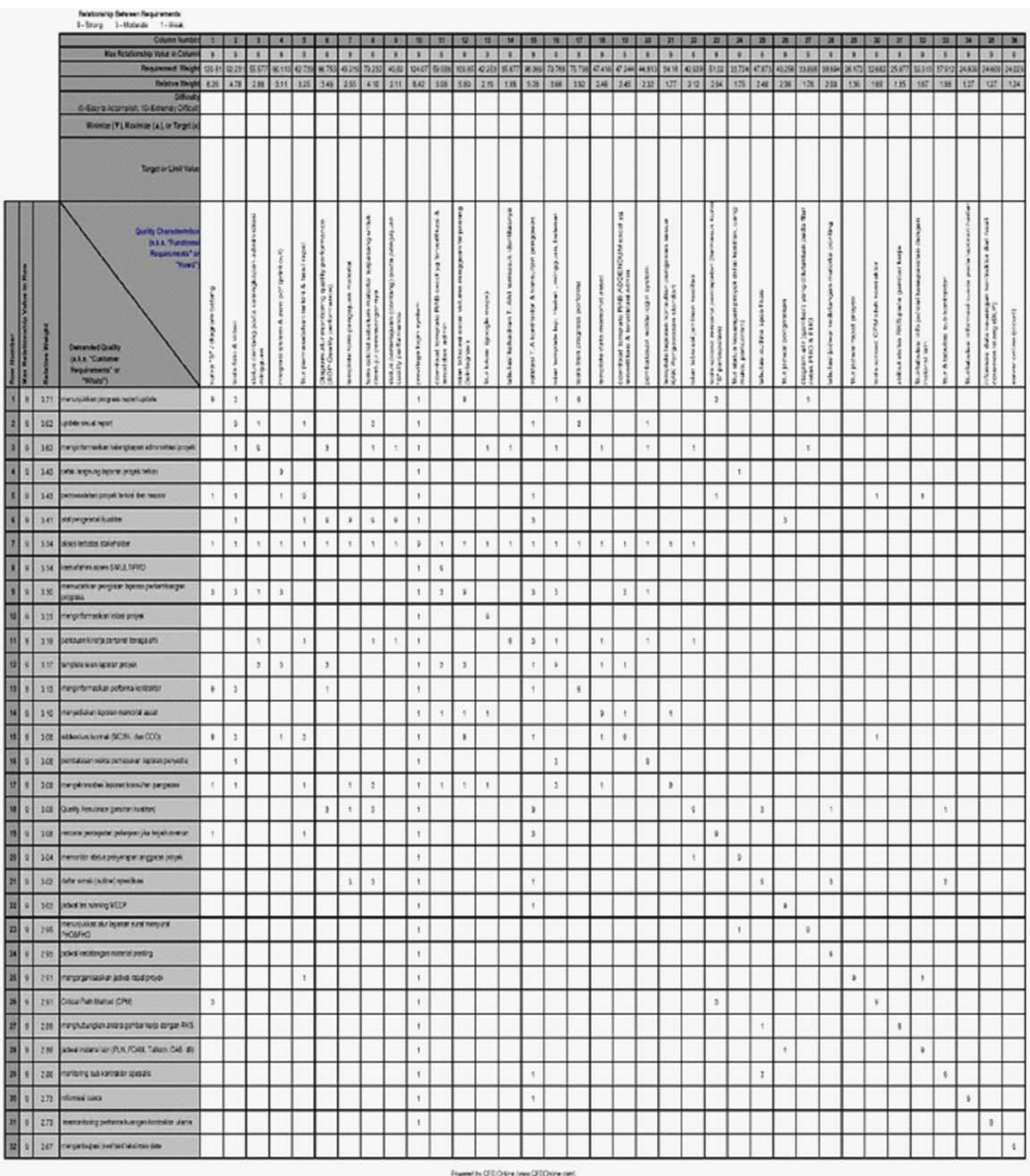


Tabel 6 Correlation Functional Requirements

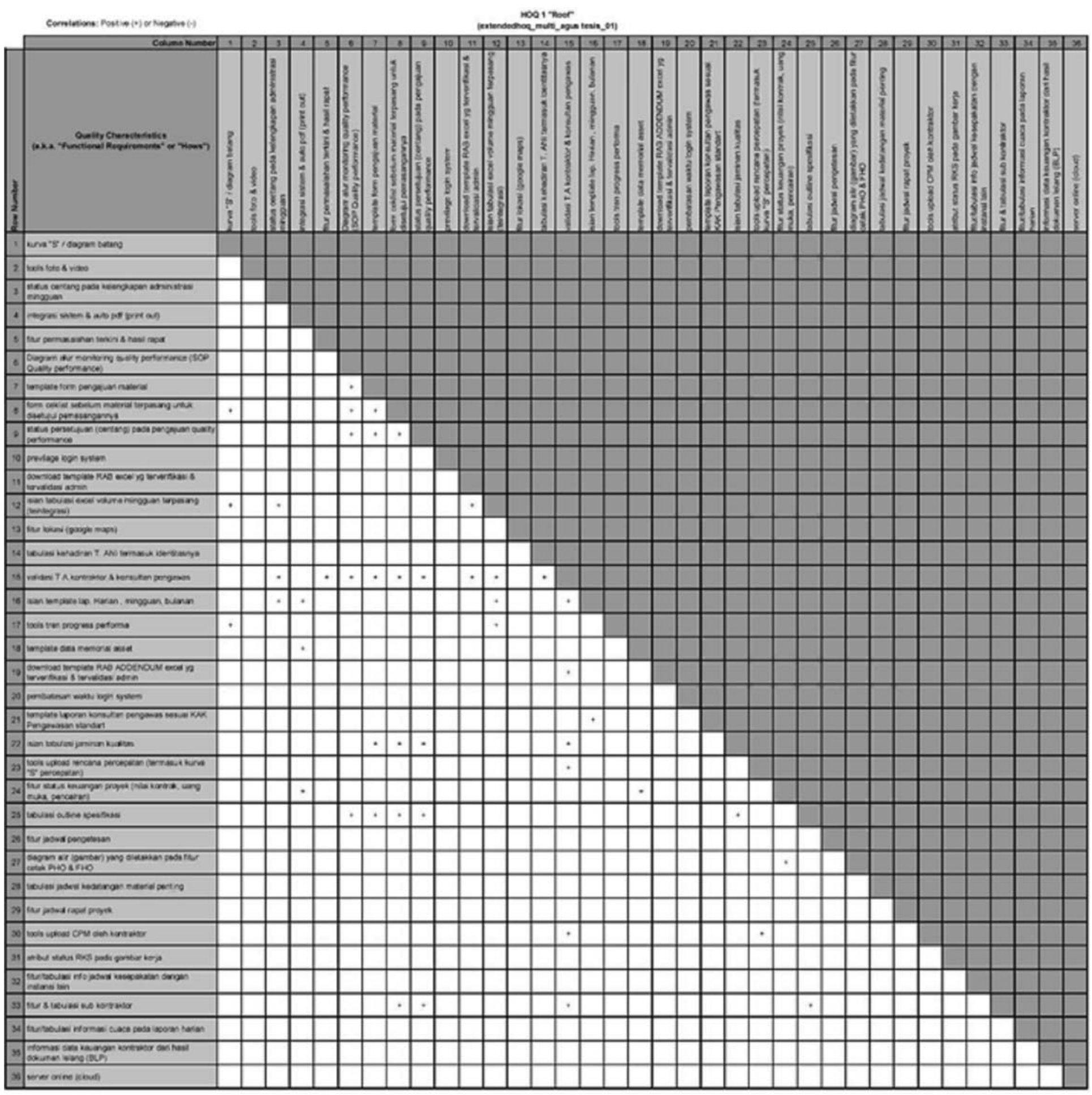


Agus Siswanto \& Imam Baihaqi, Identifikasi Kebutuhan Sistem Monitoring dan Pengendalian Multi-Proyek Konstruksi dengan Metode House of Quality

Tabel 7 Kesimpulan HoQ

\begin{tabular}{|c|c|c|c|c|}
\hline $\begin{array}{c}\text { Row } \\
\text { Number }\end{array}$ & $\begin{array}{c}\text { Quality Characteristics } \\
\text { (a.k.a. "Functional Requirements" or "Hows") }\end{array}$ & $\begin{array}{c}\text { Max } \\
\text { Relationship } \\
\text { Value }\end{array}$ & $\begin{array}{l}\text { Requirement } \\
\text { Weight }\end{array}$ & $\begin{array}{c}\text { Relative } \\
\text { Weight } \\
\text { (Relative } \\
\text { Importance) }\end{array}$ \\
\hline 1 & privilege login system & 9 & 124.07 & $6.42 \%$ \\
\hline 2 & kurva "S"/diagram batang & 9 & 120.81 & $6.26 \%$ \\
\hline 3 & $\begin{array}{l}\text { isian tabulasi excel volume mingguan terpasang } \\
\text { (terintegrasi) }\end{array}$ & 9 & 109.85 & $5.69 \%$ \\
\hline 4 & validasi T.A kontraktor $\&$ konsultan pengawas & 9 & 98.07 & $5.08 \%$ \\
\hline 5 & tools foto \& video & 9 & 92.23 & $4.78 \%$ \\
\hline 6 & $\begin{array}{l}\text { form checklist sebelum material terpasang untuk disetujui } \\
\text { pemasangannya }\end{array}$ & 9 & 79.23 & $4.10 \%$ \\
\hline 7 & tools tren progress performa & 9 & 75.74 & $3.92 \%$ \\
\hline 8 & isian template lap. Harian, mingguan, bulanan & 9 & 70.77 & $3.66 \%$ \\
\hline 9 & $\begin{array}{l}\text { Diagram alur monitoring quality performance (SOP } \\
\text { Quality performance) }\end{array}$ & 9 & 66.75 & $3.46 \%$ \\
\hline 10 & fitur permasalahan terkini $\&$ hasil rapat & 9 & 62.74 & $3.25 \%$ \\
\hline 11 & integrasi sistem \& auto pdf (print out) & 9 & 60.11 & $3.11 \%$ \\
\hline 12 & $\begin{array}{l}\text { download template RAB excel yg terverifikasi \& } \\
\text { tervalidasi admin }\end{array}$ & 9 & 59.01 & $3.06 \%$ \\
\hline 13 & status centang pada kelengkapan administrasi mingguan & 9 & 55.58 & $2.88 \%$ \\
\hline 14 & $\begin{array}{l}\text { tools upload rencana percepatan (termasuk kurva "S" } \\
\text { percepatan) }\end{array}$ & 9 & 51.02 & $2.64 \%$ \\
\hline 15 & template form pengajuan material & 9 & 49.22 & $2.55 \%$ \\
\hline 16 & tabulasi outline spesifikasi & 9 & 47.87 & $2.48 \%$ \\
\hline 17 & template data memorial asset & 9 & 47.42 & $2.46 \%$ \\
\hline 18 & $\begin{array}{l}\text { download template RAB ADDENDUM excel yg } \\
\text { terverifikasi \& tervalidasi admin }\end{array}$ & 9 & 47.24 & $2.45 \%$ \\
\hline 19 & pembatasan waktu login system & 9 & 44.81 & $2.32 \%$ \\
\hline 20 & fitur lokasi (Google Maps) & 9 & 42.25 & $2.19 \%$ \\
\hline 21 & isian tabulasi jaminan kualitas & 9 & 40.93 & $2.12 \%$ \\
\hline 22 & $\begin{array}{l}\text { status persetujuan (centang) pada pengajuan quality } \\
\text { performance }\end{array}$ & 9 & 40.82 & $2.11 \%$ \\
\hline 23 & fitur jadwal pengetesan & 9 & 40.26 & $2.08 \%$ \\
\hline 24 & tabulasi jadwal kedatangan material penting & 9 & 38.69 & $2.00 \%$ \\
\hline 25 & fitur \& tabulasi sub kontraktor & 9 & 37.91 & $1.96 \%$ \\
\hline 26 & tabulasi kehadiran T. Ahli termasuk identitasnya & 9 & 35.68 & $1.85 \%$ \\
\hline 27 & $\begin{array}{l}\text { template laporan konsultan pengawas sesuai KAK } \\
\text { pengawasan standar }\end{array}$ & 9 & 34.18 & $1.77 \%$ \\
\hline 28 & $\begin{array}{l}\text { diagram alir (gambar) yang diletakkan pada fitur cetak } \\
\text { PHO \& FHO }\end{array}$ & 9 & 33.90 & $1.76 \%$ \\
\hline 29 & $\begin{array}{l}\text { fitur status keuangan proyek (nilai kontrak, uang muka, } \\
\text { pencairan) }\end{array}$ & 9 & 33.72 & $1.75 \%$ \\
\hline 30 & tools upload CPM oleh kontraktor & 9 & 32.68 & $1.69 \%$ \\
\hline 31 & fitur/tabulasi info jadwal kesepakatan dengan instansi lain & 9 & 32.31 & $1.67 \%$ \\
\hline 32 & fitur jadwal rapat proyek & 9 & 26.17 & $1.36 \%$ \\
\hline 33 & atribut status RKS pada gambar kerja & 9 & 25.98 & $1.35 \%$ \\
\hline 34 & fitur/tabulasi informasi cuaca pada laporan harian & 9 & 24.61 & $1.27 \%$ \\
\hline
\end{tabular}




\begin{tabular}{|c|l|c|c|c|}
\hline 35 & $\begin{array}{l}\text { informasi data keuangan kontraktor dari hasil dokumen } \\
\text { lelang (BLP) }\end{array}$ & 9 & 24.61 & $1.27 \%$ \\
\hline 36 & server online (cloud) & 9 & 24.02 & $1.24 \%$ \\
\hline
\end{tabular}

3. House of quality secara terstruktur dan sistematis mampu menuntun langkah-langkah identifikasi kebutuhan sistem monitoring dan pengendalian multi proyek konstruksi.

\section{Saran}

Beberapa hal yang perlu mendapat perhatian lebih lanjut untuk penyempurnaan penelitian ini adalah sebagai berikut.

1. Dalam menentukan nilai hubungan antara customer requirements dengan functional requirements dan pemberian nilai korelasi antarfunctional requirements perlu melibatkan beberapa orang ahli atau kelompok diskusi, mengingat pada saat melakukan hal tersebut peneliti beberapa kali mengoreksi hasil penilaiannya sendiri dengan pertimbangan tertentu.

2. Perlu ada langkah lanjutan yaitu penelitian lebih lanjut validasi terhadap identifikasi kebutuhan sistem dengan cara pengembangan prototype sistem.

3. Menurut persepsi peneliti, terdapat kekurangan dari penelitian yang dilakukan untuk dapat dikembangkan lebih lanjut oleh peneliti lain di antaranya: perlu dilakukan pendekatan analisis dengan menggabungkan quality function deployment (QFD) dan analytical network process (ANP) untuk membimbing desain sistem monitoring dan pengendalian pada multi proyek konstruksi yang lebih kompleks.

\section{DAFTAR PUSTAKA}

Akao, Y. 1994. Development History of Quality Function Deployment. The Customer Driven Approach to Quality Planning and Deployment. Minato, Tokyo 107 Japan: Asian Productivity Organization.

Alwi, I. 2015. Kriteria Empirik dalam Menentukan Ukuran Sampel pada Pengujian Hipotesis Statistika dan Analisis Butir. Formatif: Jurnal Ilmiah Pendidikan MIPA, 2(2). Diambil dari http://journal.lppmunindra.ac.id/ index.php/Formatif/article/view/95.

Aritua, B., Smith, N. J., \& Bower, D. 2009. Construction Client Multi-Projects-A Complex Adaptive Systems Perspective. International Journal of Project Management, 27(1), 72-79.

Gray, C. \& Larson, E. 2011. Project Management the Managerial Process (fifth). Oregon State University: Tim VertoVec.

Guide to the Software Engineering Body of Knowledge (Version 3.0). 2014. Hoes Lane-Piscataway: IEEE Computer Society.

Hauser, J., \& Clausing, D. 1988. The House of Quality. Harvard Business School.

Irawan, I.P.D. \& Syairudin, B. 2015. Penjadwalan Multi Proyek Pembangunan Tower Pemancar Pt Smartfren !!Ecom di Surabaya Menggunakan Metode Critical Chain. Prosiding Seminar Nasional Manajemen Teknologi XIX. Diambil dari http://mmt.its.ac.id/ download/SEMNAS/SEMNAS\%20XXII/ 
MTL/25.\%20Prosiding\%20\%20I\%20

Putu\%20Dodi\%20Irawan\%20-\%20Ok.pdf

Lam, J.S.L. 2015. Designing a Sustainable Maritime Supply Chain: A Hybrid QFD-ANP Approach. Transportation Research Part E: Logistics and Transportation Review, 78, 70-81. https://doi.org/10.1016/j.tre.2014. 10.003

Peraturan Menteri Pekerjaan Umum dan Perumahan Rakyat Republik Indonesia Nomor: 31/PRT/M/2015. 2015. Jakarta: JDIH Kementerian PUPR.
Potter, N., \& Sakry, M. 2014. Software Requirements (3rd ed.). US: The Process Group. QFD Online - Free House of Quality (QFD) Templates for Excel. (n.d.). Diambil 22 Mei 2017, dari http://www.qfdonline.com/ templates/

Santosa, B. 2009. Manajemen Proyek Konsep dan Implementasi (Pertama). Yogyakarta.

Tapke, J., Muller, A., Johnson, G., \& Sieck, J. 1997. House of Quality. Diambil dari https://www.thecorporaterookie.com/wpcontent/uploads/2014/06/HOQ.pdf. 
Accounting and Management Journal, Vol. 1, No. 2, December 2017 